\title{
Research on Brand Marketing of Tourist Destination in China
}

\author{
Jungang Jin ${ }^{1, a}$ \\ ${ }^{1}$ Xi'an International University, Xi'an, Shaanxi, China, 71007
}

Keywords: Tourism Destination; Brand Marketing; Strategy

\begin{abstract}
Tourism destination has become an important object of contemporary tourism marketing. By sorting out some related concepts of tourism destination marketing in China, this paper analyzes the key influencing factors of tourism destination brand marketing and puts forward some countermeasures and suggestions.
\end{abstract}

\section{Introduction}

Chinese tourism industry gets more and more intense competition, which clearly manifested in the tourism destination between the competitions. Therefore, destination marketing as an important destination management has become an important means for many tourist destinations to gain a competitive advantage. Thus, the theory of tourism destination marketing and a variety of application issues also naturally become the focus of academic attention.

\section{The Definition of Related Concepts}

Tourism Destination Marketing and Tourism Destination Branding. Tourism destination marketing. According to the study, it is concluded that the tourism destination marketing can be summarized as: the regional tourism organization distinguishes and establishes the target market of the destination tourism product, provides the information of the tourist destination, highlights the image of the tourist destination and builds the scenic attraction; attracts the potential of the destination The attention of tourists, induced by the tourist destination yearning, and then produce tourism consumption.

Tourism destination branding. The American Marketing Association defines the brand as "the name, text recognition, logo, symbol, style, and combination of products and services provided by the seller or seller group that are distinctly different from the competitor."

Tourism Destination Brand Marketing and Tourism Destination Marketing, Tourism Destination Branding. Tourism destination brand marketing. Tourism destination brand marketing is an extremely complex and highly politicized activity, so researchers at home and abroad do not have a unified and clear concept for it. Based on the existing research results, I believe that the tourism destination brand marketing is based on the establishment and development of the destination brand as the goal, the marketing means taken to achieve the destination "brand"; it is a comprehensive and coherent business process, in addition to attract tourists can also attract investors to the destination of tourism economic investment and cooperative development.

The relationship between tourism destination brand marketing and tourism destination marketing. In the modern tourism market, building and maintaining brand value is the key to the success of a destination. According to the World Tourism Organization's forecast, contemporary tourism consumption is clearly tending to the famous destination brand. One of the few major destinations attracts the world $2 / 3$ of the tourism market.

The relationship between tourism destination brand marketing and tourism destination brand. The ultimate goal of branding is to create a positive destination image, although the definition of tourism destination branding is also based on it is a series of marketing activities, but the brand is a marketing strategy, it and the destination image, positioning are part of the destination marketing activities. To sum up, the destination brand is just a marketing tool, in order to achieve the tourist destination of self-image. 
Tourism destination brand marketing is the key to the brand, to create a unique personality of the brand, the establishment of brand and travel between the feelings of the brand is the key to marketing. While the success of the brand needs to have a certain brand of its own brand, but the strategic image management (SIM: Strategic Image Management) is only an indispensable step in the destination brand marketing, not as a destination brand for the purpose of communication and strengthen the purpose to position the established self-image.

Therefore, the destination branding is only a step in the marketing process of the destination brand and a means that can be used. The final destination travel destination and destination branding should go to the destination brand marketing.

\section{The Key Factors Impacting the Tourism Destination Brand Marketing}

The Establishment of the Destination Brand Interest Pyramid. A key factor in brand marketing is the degree to which brand personality interacts with the target market. In general, the strong brand is often the most rich personality of the brand. Now many tourist destination brand construction more casual: "great beauty", "hospitality", "natural" and so on to describe the characteristics of the vocabulary of the brand everywhere. Destination brand personality can be divided into many levels and the bottom is to consider the objective of this tourist destination, what can be measured characteristics? Objectivity is the most important quality of the target brand personality, but also the most difficult to do. The starting point of the destination brand should not be the destination itself, but from the tourists and the market began. To build a brand that can be widely recognized by tourists and widely disseminated can be studied by the relationship between tourists and the brand. The pyramid of brand interest sums up the relationship between the brand and the tourist. You can use the interests of the pyramid as a tool to extract the destination image to highlight the core point, this point is the needs of tourists and destination characteristics, the destination can provide the core interests of the intersection of the three, the destination brand marketing any activities are should focus on this essence.

Establish the Brand Image. After the establishment of the core brand value, the need to form a brand image that allows tourists to identify, and allows visitors to identify the brand image through a series of elements to reflect. For example, color, animal image, character image, scene and so on. Brand image to clearly reflect the vision (that is, all stakeholders and tourists must agree), so in the latter part of the marketing campaign, the destination brand to successfully express a credible, clear view, and cause tourists the resonance.

Establish the Destination Brand System Structure. The destination brand architecture includes the market positioning of the destination, the rational interests, the emotional interests, the communication with the tourists and the brand personality. Because the destination is a geographically integrated area, the destination brand contains multiple elements. The destination brand marketer must be aware of the interrelationships among the various factors and the contribution of each factor to the brand value. And the establishment of the brand structure system will be able to reflect all the core values of the destination brand, is conducive to marketers clearly understand the composite elements of the brand and the interaction between them.

\section{The Tourism Destination Brand Marketing Strategy}

Make Clear Brand Positioning and Focus on Brand Core Value Mining. The first step in any brand marketing is to build the core value of the destination brand, which should be persistent, relevant, easy to spread, for the potential value of the tourists, which need to consider the brand and the tourists the relevance of the brand, the novelty of the brand, and the difference between the brand and the competitor's brand. Therefore, the first stage of tourism destination brand marketing should be the conduct of market research, analysis and strategic choice. Through surveys to visit local tourism businesses, economists, previously visited local visitors and never visited local tourists, other similar destinations, and even local community residents. These surveys and analyzes will help build brand value and brand characteristics. Tourism destination brand marketing needs of 
the tourist destination brand core values and relative competitive advantage clear, according to local conditions for brand positioning. Travel destination brand positioning can work through the following three aspects:

To integrate the tourism resources within the region, the characteristics of mining out, summed up the overall tourism resources linked to the common characteristics. From the tourism resources to carry out brand positioning, both to reflect the unique attractiveness of the tourism area, but also in line with the status of the development of the local tourism industry, so that the status quo and prospects for the development of the overall tourism to promote the healthy and sustainable development.

To take into account the development of the current tourism industry trends and new changes, making the brand can be adapted to meet market demand to meet the diversified, personalized trend.

According to the tourist area within the characteristics of the source market characteristics of targeted analysis and integration, to draw a target to attract tourists from the tourist brand to meet its increasingly personalized, experiential tourism needs, but also for the later tourism brand marketing lay the foundation, do pave the way.

Shape the Brand Image and Focus on Brand Identity Design. Tourism destination brand marketing content of the most important part is to shape its brand image. Once the brand image is established, it may be difficult to change the whole, because it is easier to set up a new image than to refute an old image. The destination brand is not out of thin air, the choice of tourists to the destination is not unfounded, so the destination must highlight their own brand image and other major competitors compared to the unique, so that tourists realize that the destination has a base market that is different from other places.

Tourism brand logo design to meet the region's tourism resources and the status of tourism development, so that the status quo and prospects for the development of tourism resources as a basis; unique, tourism brand logo to highlight the brand connotation, can be found throughout the regional tourism core competitiveness, to show different from other tourist areas of the outstanding features; vivid, tourism brand logo to be visually colorful, rich and vivid, creative highlights, highlighting the characteristics of the tourism area on the basis of refreshing and memorable. At the same time, the tourism brand slogan set the size of the situation, according to local conditions, pay attention to the current development of tourism trends, to meet the needs of the public tourism to keep up with the pace of the times; to be simple and powerful, easy to understand, integrated summed up the most representative and strong appeal, the appeal of the statement, so that the audience widely accepted and easy to remember, blurted out; requirements highlight the characteristics of innovation and differences, the formation of different geographical characteristics of other tourist areas, so as to attract tourists to promote the brand.

Integrate Communication Resources and Focus on Brand Promotion. Tourism brand marketing quality and brand communication are closely related. Tourism destination brand promotion needs to integrate resources, integration of ways, rich brand communication increase brand communication. Specifically from four aspects:

Advertising promotion. In the production of advertising content, the region should be a high degree of integration of tourism resources, the essence of its extracted, and through the rich image of the form of vivid, creative and creative advertising and media video short film publicity for a wide range of publicity; Advertising media selection, the authority of the media within the region and the authority of the media within the country is the first choice, with its extensive coverage to expand the visibility of tourism brands.

PR promotion. Tourism brand public relations include journalists, all kinds of selection activities, festivals, seminars and other forms. In the tourism brand of public relations, to maintain a wide range of contacts with the government to obtain their support and consent, and with the relevant enterprises to achieve appropriate cooperation to achieve a win-win situation; to focus on interaction with the audience, making the target group broad participation in deepening for the brand's impression. 
Promotion. For the promotion of tourism brand promotion, you can use the major festivals and more scenic spots linked to price concessions, or with the enterprise jointly launched preferential activities.

Network promotion. Tourism brand promotion needs to be relatively open, with a certain economic income and leisure time of the crowd, therefore, can use the network and micro-blogging to promote the brand is a good choice; the establishment of the region's tourism official website and micro-blogging, providing real-time and accurate travel information, focusing on interactivity with visitors.

\section{References}

[1] Nigel Morgan et. Tourism Destination Brand Management[M]. Yang Guihua, translated. Tianjin: Nankai University Press, 2006.

[2]Steven Pike.Destination brand positions of a competitive set of near - home destinations [J] .Tourism Management, 2009 (30) : 857- 866.

[3]Jones , C.B.The New Tourism and Leisure Environment[EB/OL].World Tourism Organization.www.econres.com/1998.

[4]Kotler, P.and Gertner, D. Country as brand product and beyond: A place marketing and brand management perspective[J].Journal of Brand Management， 2002， 9 （4-5）:249-261

[5] Nie Youbing. On the tourist destination brand marketing approach [J]. Enterprise Herald, 2012 (09) 